\title{
A Study on the Usage of Electronic Books of Undergraduates of Uva Wellassa University of Sri Lanka
}

D. P. C. Vithana ${ }^{1}$

\begin{abstract}
The electronic books' (e-books) usage of the higher education community is exponentially expanding. There are a significant percentage of university students and staff who prefer e-books to printed books. This comprehensive study is done at Uva Wellassa University to analyze the percentage of undergraduates who are inclined to use e-books and to explore their preferences over e-book format, reading equipment, their purpose and obtaining method. The study also reveals the future preference and predictions of e-book usage in Sri Lankan context. It also discusses the comparative advantages and disadvantages of e-books according to the survey results gained through the open ended questions. Both qualitative and quantitative methods are used in this study. A survey was distributed among the undergraduates who represent first to fourth years in Management Faculty, Animal Science and Export Agriculture Faculty and Science Faculty in Uva Wellassa University. The sample size is 206. The paper concludes that there is a significant number of e-book uses in the university. The e-book usage is limited due to the limited number of freely available e- books. Most of the tested cohort predicts of increased number of e-book usage in Sri Lanka in the future. Data suggest that with the undergraduate year of the user the usage of e-books is increased. The e-book usage is independent from gender. Yet it is dependent upon the Faculty. Users are inclined to use personal computers and laptops than the e-readers. The main e-book obtaining method of the user is internet and they generally go for free titles. According to the statistics the main e-book reading purpose is education. The study suggests the need of establishing e-book facilities in Uva Wellassa University.
\end{abstract}

Keywords: Electronic books, Library Usage, Undergraduates, Uva Wellassa University

\footnotetext{
${ }^{1}$ Assistant Librarian, Uva Wellassa University of Sri Lanka.Email: palikav6@gmail.com
} 


\section{Introduction}

The technological world is highly evolving. With this exponential evolution the library user needs are changing. Most library users, who occasionally visited the library to obtain information, now search through the internet. They are seeking easy access to the information. But they do not consider the reliability of the information retrieved. In such a scenario most e-books provide reliable information to the user. However in Sri Lankan setting, obtaining e-books is a challenge. This is due to the unavailability of e-book repositories in the libraries and the high costs of e-books. Currently the ebooks using community is limited to higher education sector. The study is conducted to analyze the e-book usage of undergraduates. The tested cohort is Uva Wellassa University undergraduates.

\section{Literature Review}

This survey is done with the generation-Y members, also known as Millennials. They were born between the late 1970s and the late 1990s. This generation is highly internet oriented and growing in an increasingly globally connected world (Tosun, 2014). Uva Wellassa University library is currently catering the needs of such a generation. The study is conducted to perceive the needs of technology oriented undergraduates.

Mashroofa (2013) conducted a study at University of Jaffna, Eastern University, Sri Lanka and South Eastern University of Sri Lanka found out that $81.4 \%$ of respondents prefer electronic materials than print materials. According to the study e-books \& e- journals usage of freshmen in those universities is $6.4 \%$.

Most of the global studies conducted about e-books are in relation to usage of available e-book repositories in their libraries. This study was conducted to analyze the need of e-book repository for Uva Wellassa University (higher education institution) in Sri Lanka.

According to the Oxford dictionary, e-book is an electronic version of a printed book which can be read on a computer or a specifically designed 
handheld device. Software such as PDF, ePub, PRC, and MOBI etc. are used to read the e-books. The software has facilities to add bookends, mark text, take notes, etc.). This allows the user to conduct the same functions performed during traditional reading. Devices such as CD/DVD ROM, PCs, laptops, Smart phones (iPhone and Android phones), Tablets (iPad or the numerous tablets that run the Android operating system) and e- readers (Amazon's Kindle, Barnes \& Noble's NOOK, Kobo, Sony Reader) are used to read e books. The move towards e-book reading coincides with an increase in ownership of electronic book reading devices (Rainie \& Duggan, 2012). The number of owners of either has a tablet computer or e-book reading device such as a Kindle or Nook grew from 18\% in late 2011 to 33\% in late 2012 in America. As of November 2012, some 25\% of Americans ages 16 and older own tablet computers such as iPads or Kindle Fires, up from 10\% who owned tablets in late 2011. And in late 2012, 19\% of Americans ages 16 and older own e-book reading devices such as Kindles and Nooks, compared with 10\% who owned such devices at the same time in 2011 (Rainie \& Duggan, 2012).

According to Tosun, (2014) the increase in the number and types of hardware and software required to read e-books is indicative of the rise in the number of e-book readers and e-books released by the publishing industry. He also mentioned that due to the technological support e-books provides an appeal to students with different learning styles. In addition due to its visual and audio elements, e-books could facilitate learning and teaching and make it more enjoyable. According to his findings only $20.9 \%$ of the students currently read e-books in Trakya University, Faculty of Education, in Turkey. His findings suggest that $14.8 \%$ of female students and $34.1 \%$ of male students read ebooks. The rate of male students reading e-books is higher than the female students. According to chi square test of independency done in his study the e-book usage is gender dependent. His study states that $79.1 \%$ of students do not read e-books. The most important factor for the preference of students' on printed books is the cost.

According to Tosun, (2014) there is a significant relationship between the ebooks usage and the divisions of the faculty. The relationship was calculated using the chi square test. The divisions considered here are Computer Education and Instructional Technologies (CEIT), Music Education (ME), 
Preschool Education (PE), Primary School Education (PSE), Social Sciences Education (SSE) and Turkish Language Education (TLE) in Faculty of Education, Trakya University.

Chiong et al. (2012) commented that today's e-books, including those designed for the iPad, Kindle Fire, and NOOK Color, have evolved from platforms displaying simple digitized versions of print books (basic) to tools that can support highly interactive, multimedia experiences (enhanced).

A survey conducted in University of California Libraries, by Li, Poe, Potter, Quigley, \& Wilson (2011), for Springer as an e-book pilot project, 58\% of survey respondents reported using Academic e-books; 38\% reported not using e-books; and 4\% were not sure of their e-book usage. From those who are reporting not using e-books, the majority report utilizing digital resources, such as e-journals. Of the total respondents, $58 \%$ reported using e-books in their academic work; $38 \%$ reported not using e-books in their academic work; and $4 \%$ were not sure of their e-book usage.

According to the statistics of a survey of e-book usage in Survey of e-book Usage in U.S. Academic Libraries (2012) the e-book usage/circulation for the 2010-2011 academic year, on average, was 24,700, up considerably from the reported e-book circulation figure of 6,849 in 2009-2010. There was a major surge of undergraduate - circulation. As for the most preferred e-book format, basic PDF remains the preferred format for academic users. The percentage of PDF usage in 2012 is $59 \%$.

The study conducted by Renner (n.d.) indicated -all the librarians involved in the study predicted a future for e-books in the academic realm and all believe that there will be a far-reaching transition to electronic books. However, numerous challenges remain, such as licensing agreements and access arrangements. The study further states that the evolution of users away from print toward electronic books will take at least another 5-10 years, although researchers in some disciplines and younger users may make this transition more rapidly. 
Many libraries recognize that e-books offer an ideal opportunity to increase existing collections while enhancing users' research experiences at the same time. Some libraries have adopted significant e-books acquisition programs. However, some librarians agreed that it is still early days and that the market for e-books is just developing (Renner, n.d.). Woody et al. (2010) reported that even though students have the opportunity to access technology anytime and anywhere they want, there is still a preference for reading printed books.

There are numerous advantages in e-books to libraries (Renner, n.d.). Digital delivery of e-books enables publishers to create large, cost-effective packages. These packages allow libraries to significantly increase the number of titles they can purchase and extend them to remote branches. Since any number of users can access the same e-books simultaneously, librarians cited simultaneous access. Expanded usage is a major factor in e-book acquisitions, particularly in multi-site institutions. Increased likelihood of usage was another common benefit. By eliminating physical handling and shelving of printed books as well as simplifying user searches, e-books allow librarians to reduce administrative overhead and focus their efforts elsewhere. The e-books nearly eliminate damage, loss, and security concerns. They simplify and enhance the research process by allowing users to search within documents, across specified groups of documents, and across entire catalogs within seconds. In the print world, only rudimentary usage statistics typically exist. Properly-designed e-book collections allow librarians to monitor the usage of these books in much greater detail, and at the same time support the decisionmaking about collection development and budgets.

\section{Methodology}

A questionnaire was prepared in such a way to obtain responses from both ebook users and non-e-book users. In section ' $A$ ' a question is asked to separate e-book users and non-e-book users. The e-book users should answer section ' $\mathrm{B}$ ' questions and non-e-book users should answer section ' $\mathrm{C}$ '. Both parties should answer section ' $\mathrm{D}$ '. Three open-ended questions designed to explore their attitude towards e-books. The questions are the comparative advantages, comparative disadvantages and additional comments regarding e-books. 
The questionnaire was distributed separately to each undergraduate year from first year to fourth year. Through section ' $A$ ' details of the respondent such as gender, birth year category, learning method (traditional/ Distance) faculty were recoded.

Through section 'B' e-books reading software, e-books reading equipment, ebook genre (Educational/ Entertainment/ Other), e-book sources (Internet, Library, Teacher, Other), e-books obtaining method (Purchase/ Borrow/ Obtain free titles) and printed and e-books usage were recoded. Comparative advantages and comparative disadvantages were stated in this section by the e-book users.

The section ' $C$ ' recoded the information such as the reasons for not using any e-books and the future e-book preference of non-e-book users.

The section ' $\mathrm{D}$ ' is dedicated to obtain predictions of e-books usage in the future in Sri Lanka and for any additional comments of the respondents regarding e-books.

The following information is obtained from the survey:

- e-books usage percentage of undergraduates

- e-books reading software usage

- e-books reading equipment usage

- Usage of e-books according to the genre (Educational/ Entertainment/ Other)

- User statistics of e-book sources (Internet, Library, Teacher, Other)

- User statistics according to e-books obtaining method (Purchase/ Borrow/ Obtain free titles)

- Printed and e-books usage statistics

- The future of e-books in Sri Lanka in the view of current e-book users

- The future of e-books in Sri Lanka in the view of current non e-book users

- Reasons for not using e-books

- Non e-books users future e-books preference

- The comparative advantages of e-books

- The comparative disadvantages of e-books

- Additional comments of the undergraduates about e-books 
The comparative advantages, disadvantages and additional comments about ebooks were obtained through open ended questions. The questionnaire was distributed among a random sample of all four years in all three faculties of Uva Wellassa University. From 225 questionnaires distributed 206 responses were obtained. The results were interpreted through graphical representations.

The chi square test is done to observe relationship between the e-book usage and the gender of the students. $\mathrm{R}$ statistical software is used. The chi square test is also done to observe any relationship between the e-book usage and the faculty of the students. $\mathrm{H}_{0}$ : the distribution is independent vs $\mathrm{H}_{1}$ : not independent.

\section{Findings}

\section{Statistical representation of survey responses}

The respondents of this survey are the undergraduates of Uva Wellassa University. Survey responses according $1^{\text {st }}$ year, $2^{\text {nd }}$ year, $3^{\text {rd }}$ year, $4^{\text {th }}$ year are displayed in the Figure 1. Third years shows the highest response rate.

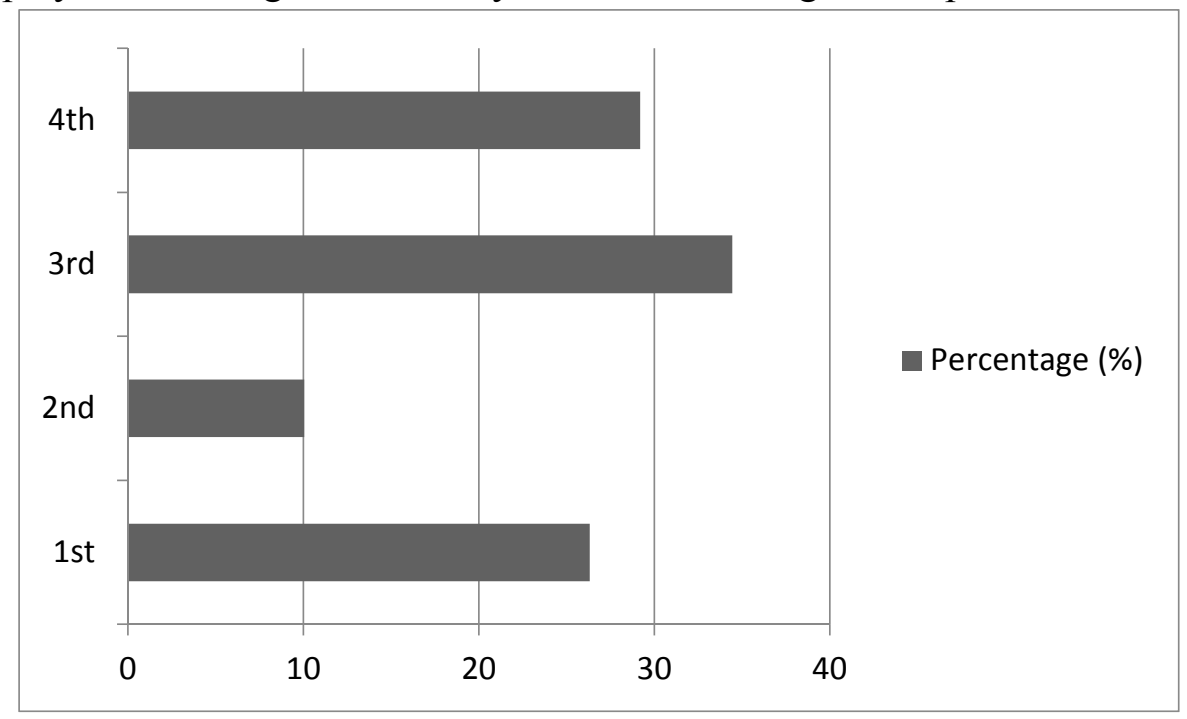

Figure 1: Respondent Percentages

\section{Male and female e-book usage statistics}

The e-book usage survey responses according to the sex are displayed in the Figure 2. There was no association between gender and e-book usage 
according to the chi squared test at 10\% significance test (chi square-1.093, df - 1, p- 0.2958).

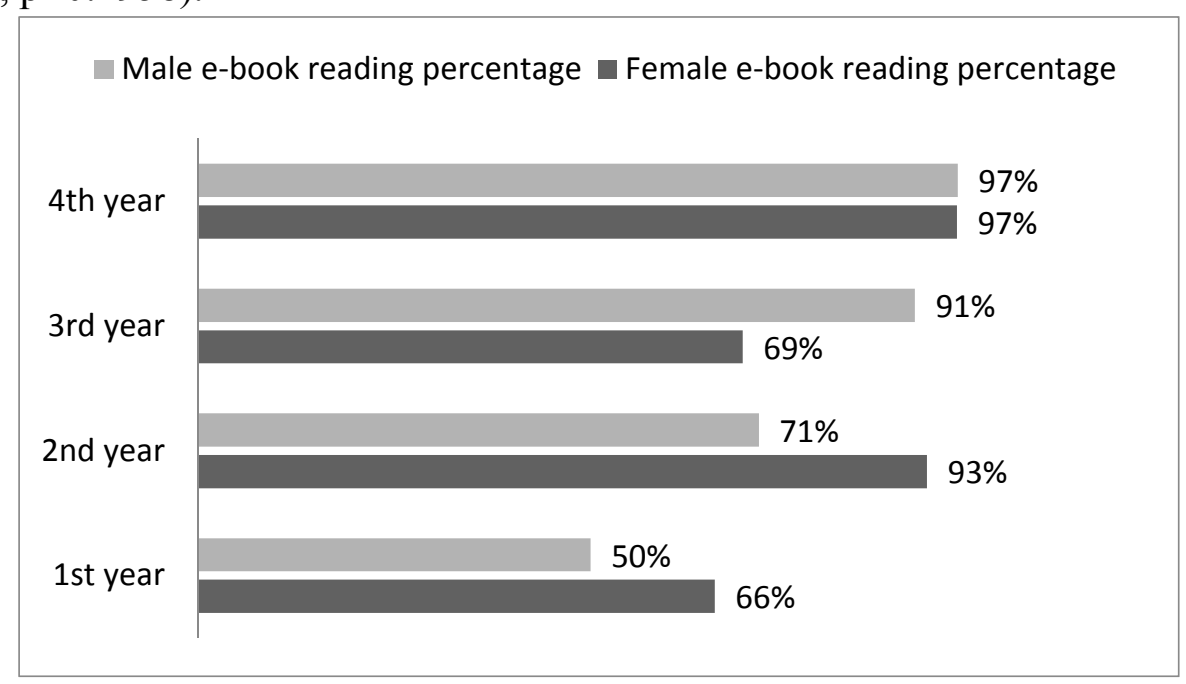

Figure 2: Male and female e-bookusage statistics

Tosun (2014) findings suggest that $14.8 \%$ of female students and $34.1 \%$ of male students read e-books. The rate of male students reading e-booksis higher than the female students. According to chi square test of independency the ebookusage is gender dependent. This finding is confirmed with the ebookusage responses gain from Uva Wellassa University according to the sex of the students. The males (84\%) of the tested cohort use e-booksthan females (77\%). Yet the chi square test of independency (2.1. section) done for this data shows that the e-bookusage is independent from the gender of students (2.2. section).

\section{Facultywise e-bookusage statistics}

The e-book usage according to the faculty are displayed in the Figure 3. There was an association between faculty and e-book usage according to the chi squared test at $10 \%$ significance test (chi square-5.3173, df - 2, p- 0.07004). 


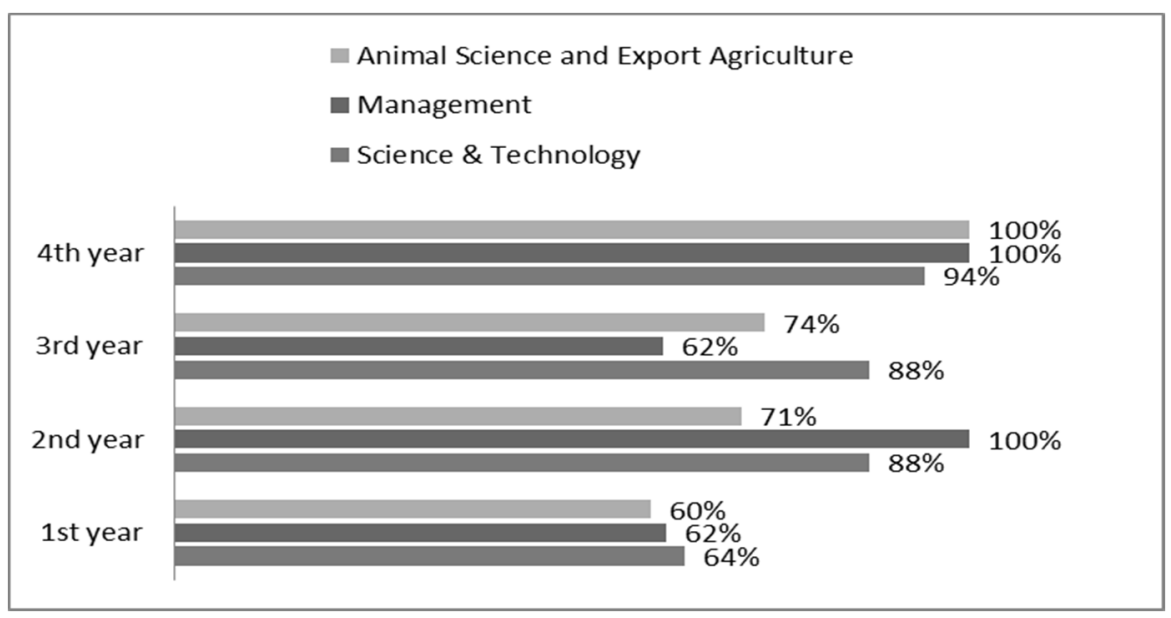

Figure 3: Faculty-wise e-book usage statistics

The faculty of Science and Technology students shows the highest e-book usage. The fourth year Animal Science and Export Agriculture students and Management students show $100 \%$ e-book usage. The second year Management students also show $100 \%$ e-book usage. The first years the faculty of Animal Science and Export Agriculture students shows the lowest $(60 \%)$ percentage of e-book usage. Yet the percentage value is comparatively higher than Faculty of Education, Trakya University, in Turkey and University of California Libraries. According to Tosun (2014) there is a significant relationship between the e-books usage and the divisions of the faculty. In Uva Wellassa University study the faculties were considered and divisions (departments) were not considered. According to the chi square test of independency (3.1. section) the e-book usage is dependent upon the faculties (3.2. section).

\section{Total e-books usage percentages}

The e-books usage percentages according to the undergraduate year are displayed in the Figure 4. The e-book usage of the tested cohort of Uva Wellassa University is $82 \%$. According Tosun (2014) findings only $20.9 \%$ of the students currently read e-books in Trakya University, Faculty of Education, in Turkey. A survey conducted in University of California Libraries, by Li et al. (2011), for Springer as an e-book Pilot Project, 58\% of survey respondents reported using Academic e-books. According to the study of Mashroofa (2013), the e-books \& e- journals usage of freshmen in the 
University of Jaffna, Eastern University and South Eastern University of Sri Lanka is $6.4 \%$. Compared to those surveys the e-book usage of freshmen at Uva Wellassa University is $62 \%$.

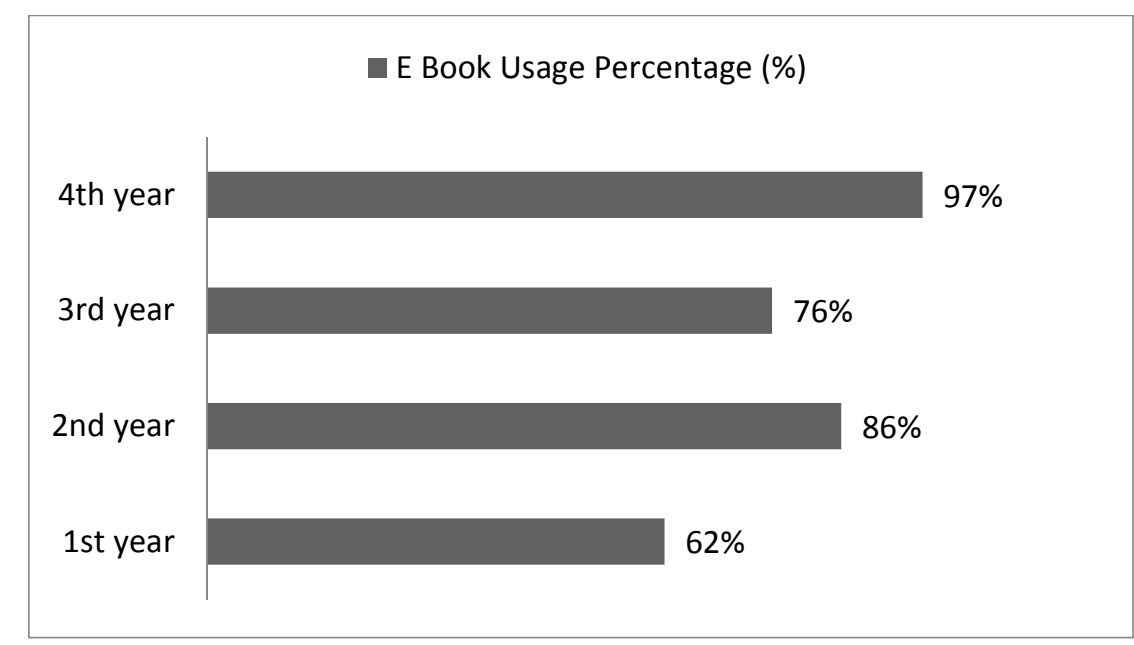

Figure 4: Total e-books usage percentages

\section{E-books reading software usage}

The e-books reading software usages are displayed in the Figure 5.

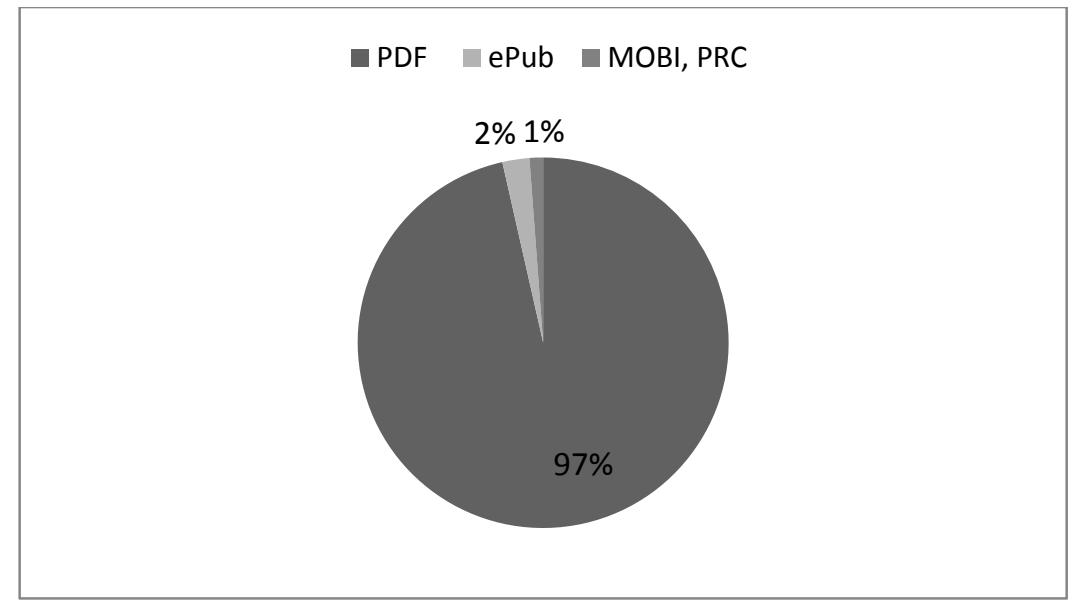

Figure 5: The e-books reading software usages

Survey of e-book usage in U.S. Academic Libraries (2012) reveals that the most preferred e-book format is basic PDF format. The percentage of PDF usage in 2012 is $59 \%$.According to the Uva Wellassa University survey data $97 \%$ of e-books users use PDF format to read e-books. 


\section{The e-books reading equipment usage}

The e-books reading equipment usages are displayed in the Figure 6. The survey reveals that $73 \%$ of e-books users use Personal Computers and laptops. Usage of e-readers such as Amazon's Kindle, Barnes \& Noble's NOOK, Kobo, and Sony Reader is very low. A survey done by Rainie \& Duggan in late 2012, conclude that $19 \%$ of Americans ages 16 and older own e-book reading devices such as Kindles and Nooks, compared with 10\% who owned such devices at the same time in 2011. Yet the case is different in Sri Lankan context. In Sri Lanka most students use Personal Computers and laptops for ebook reading purpose.

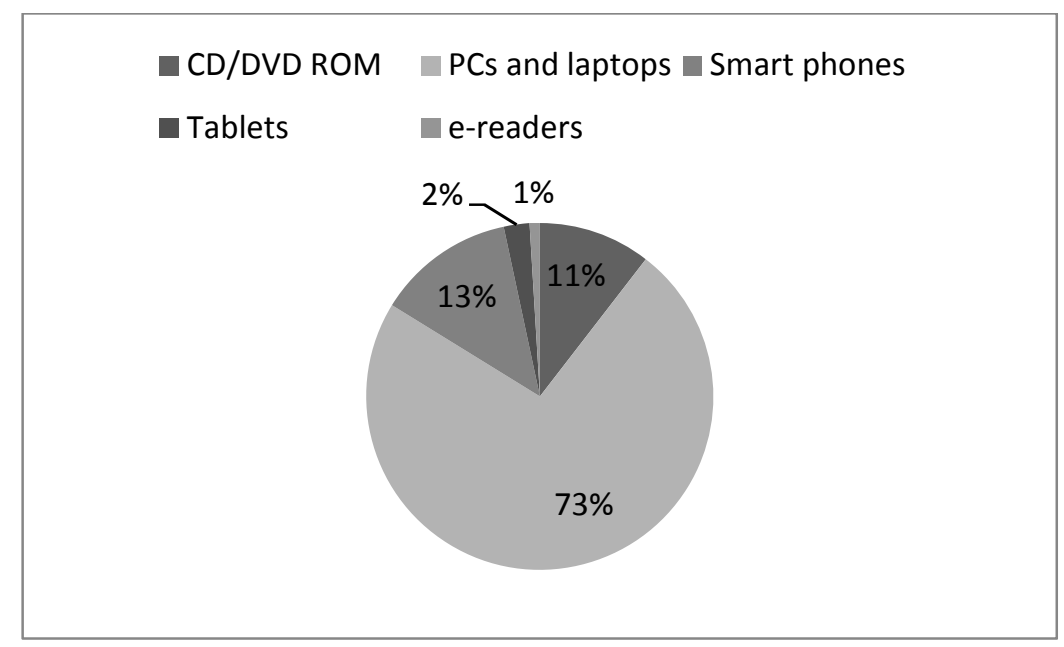

Figure 6: The e-books reading equipment usage

Usage of e-books according to the genre - Educational/ Entertainment/Other

Usage of e-books according to the genre - Educational/ Entertainment/ Other are displayed in the Figure 7. According to the Uva Wellassa University survey $73 \%$ of e-book users use e-books for educational purposes. A survey conducted in University of California Libraries, by Li et al. in 2011), for Springer as an e-book Pilot Project, 58\% reported using e-books in their academic work. The details suggest that for the tested cohort of Uva Wellassa University, the e-book usage for educational purposes is comparatively very high. 


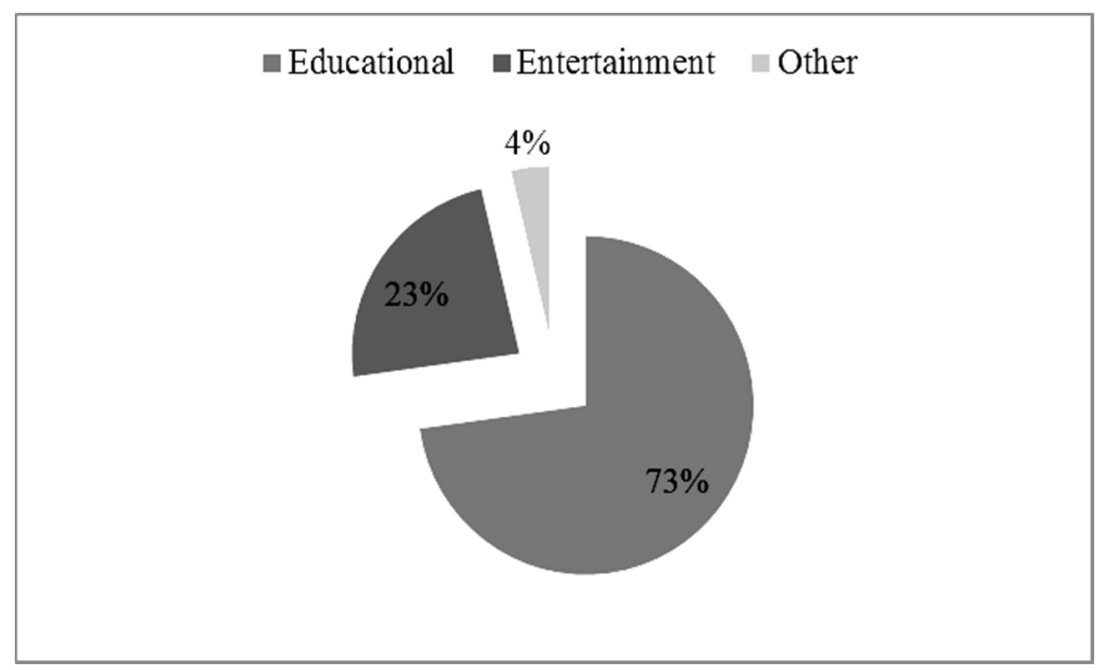

Figure 7: Usage of $\mathrm{e}$ - books according to the genre

\section{User statistics of e-book sources (Internet, Library, Teacher, Other)}

The statistics of e-books obtaining sources are displayed in the Figure 8.

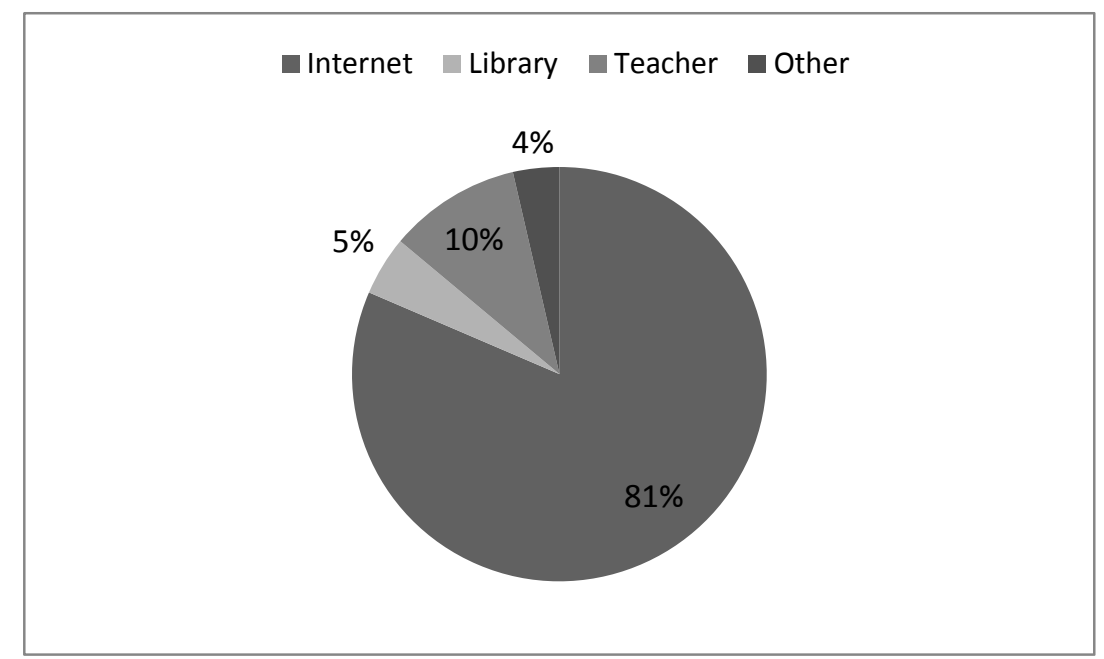

Figure 8: User statistics of e-book sources

About $81 \%$ of users obtain their e-books through internet. Highest percentages $(82 \%)$ of users obtain free e-book titles. The above data can be concluded as the students mostly use internet to obtain free e-books. 


\section{User statistics according to e-book obtaining method (Purchase/ Borrow/ Obtain free titles)}

The statistics of e-books obtaining method (Purchase/ Borrow/ Obtain free titles) are displayed in the Figure 9. Highest percentages (82\%) of users obtain free e-book titles.

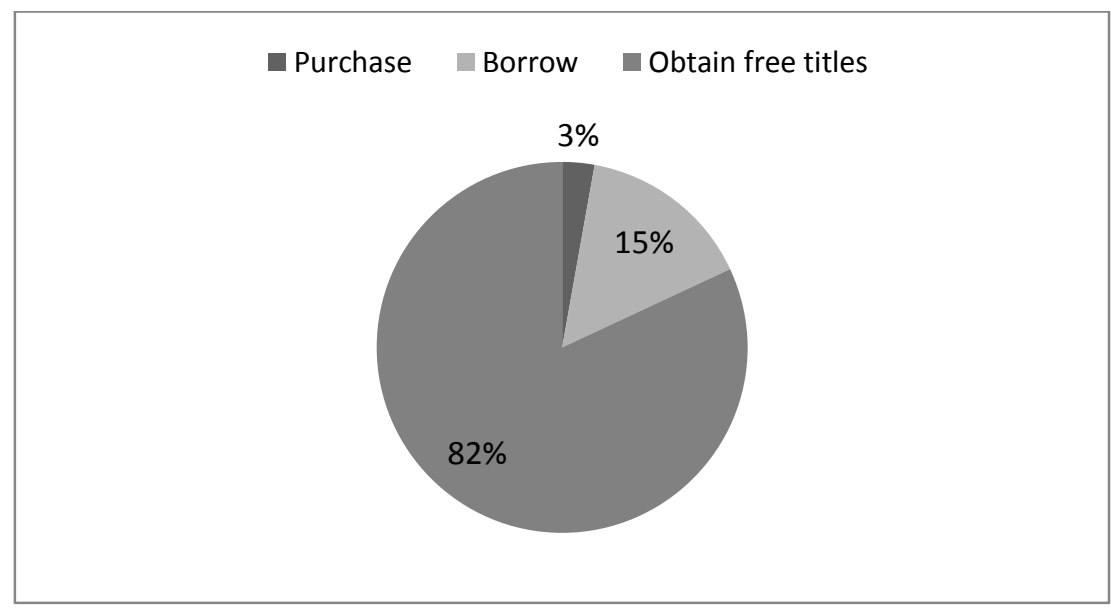

Figure 9: User statistics according to e-book obtaining method

\section{Printed and e-book usage statistics}

The statistics of e-books and printed books are displayed in the Figure 10. According to the statistics of e-books and printed books the highest number of e-book users use both e-books and printed books. Woody et al. (2010) reports that even though students have the opportunity to access technology anytime and anywhere they want, there is still a preference for reading printed books.

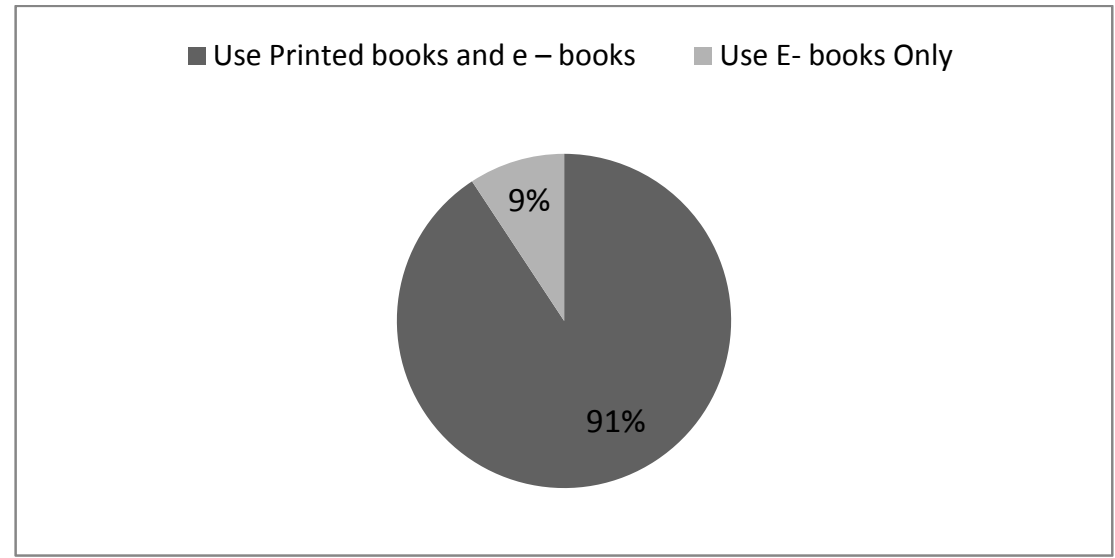

Figure 10: Printed and e-book usage statistics 


\section{The future of e-books in Sri Lanka in the view of current e-book users}

The statistics of future of e-books in Sri Lanka in the view of current e-book users are displayed in the Figure 11. The highest percentage (64\%) of current e-book users predict that e-books will be used more and more in the purpose of education in the future.

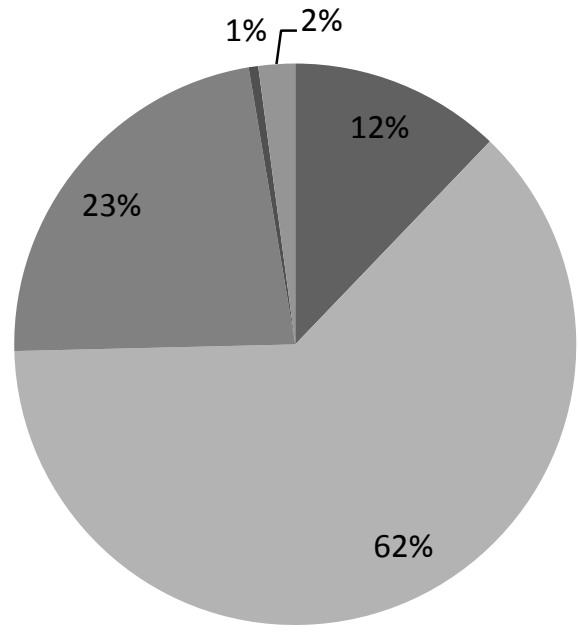

- e-books will be more and more popular in the purpose of leisure in the future

e - books will be used more and more in the purpose of education in the future

a-books will replace the printed books in the future

e - books will not be popular and removed eventually

Figure 11: The future of e-books in Sri Lanka in the view of current e-book users

\section{The future of e-books in Sri Lanka in the view of current non e-book users} The statistics of future of e-books in Sri Lanka in the view of current non ebook users are displayed in the Figure 12 . The highest percentage $(60 \%)$ of current non e-book users predict that e-books will be used more and more in the purpose of education in the future. 


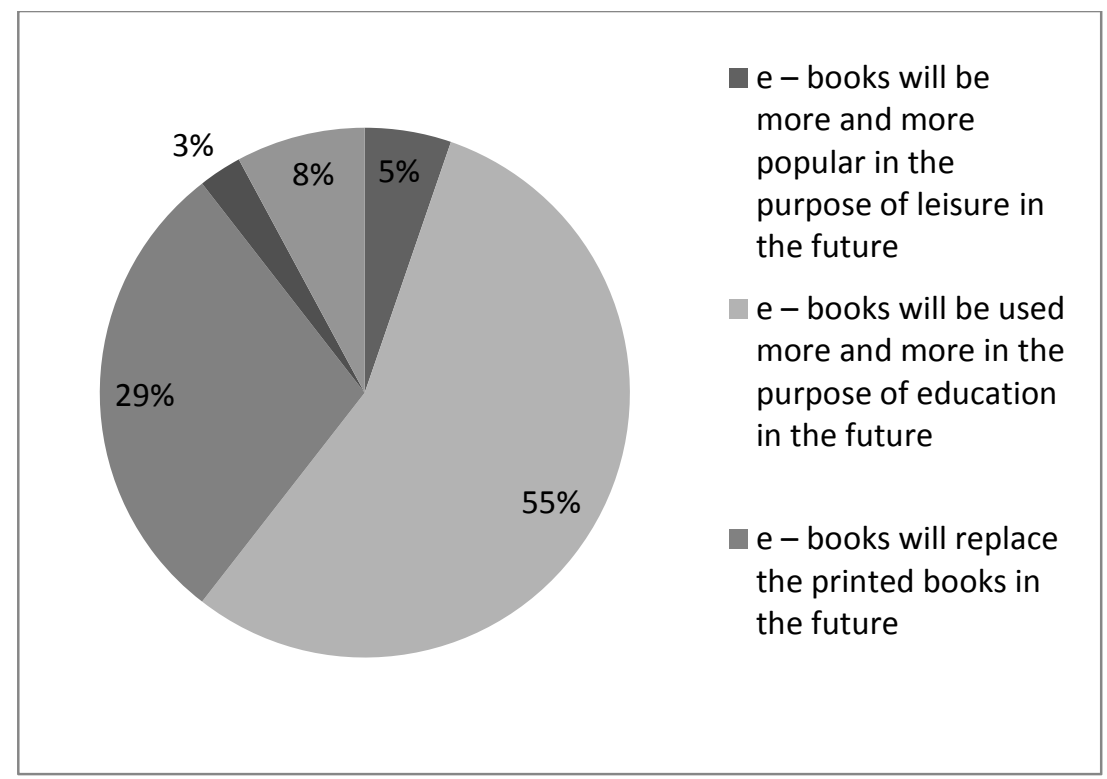

Figure 11: The future of e-books in Sri Lanka in the view of current e-book users

\section{The future of e-books in Sri Lanka in the view of all survey respondents}

The statistics of future of e-books in Sri Lanka in the view of all survey respondents are displayed in the Figure 13.

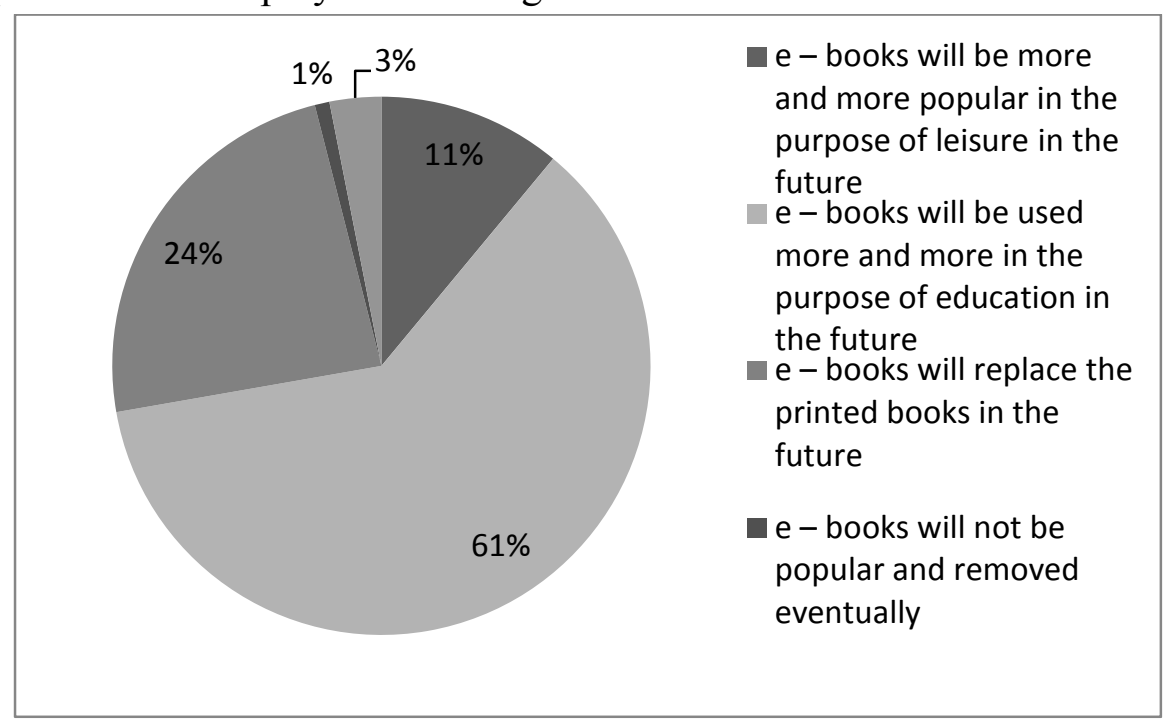

Figure 12: The future of e-books in Sri Lanka in the view of all survey respondents 
The highest percentage (64\%) of current e-book users and highest percentage $(60 \%)$ of current non e-book users predict that e-books will be used more and more in the purpose of education in the future in Sri Lanka. A significant number $(25 \%)$ of respondents predict that e-books will replace the printed books in the future in Sri Lanka. All of the librarians involved in the study conducted by Renner, n.d. predict a future for e-books in the academic realm and all believe that there will be a far-reaching transition to electronic books.

\section{Reasons for not using e-books}

The reasons for not using e-books are displayed in Figure 14.

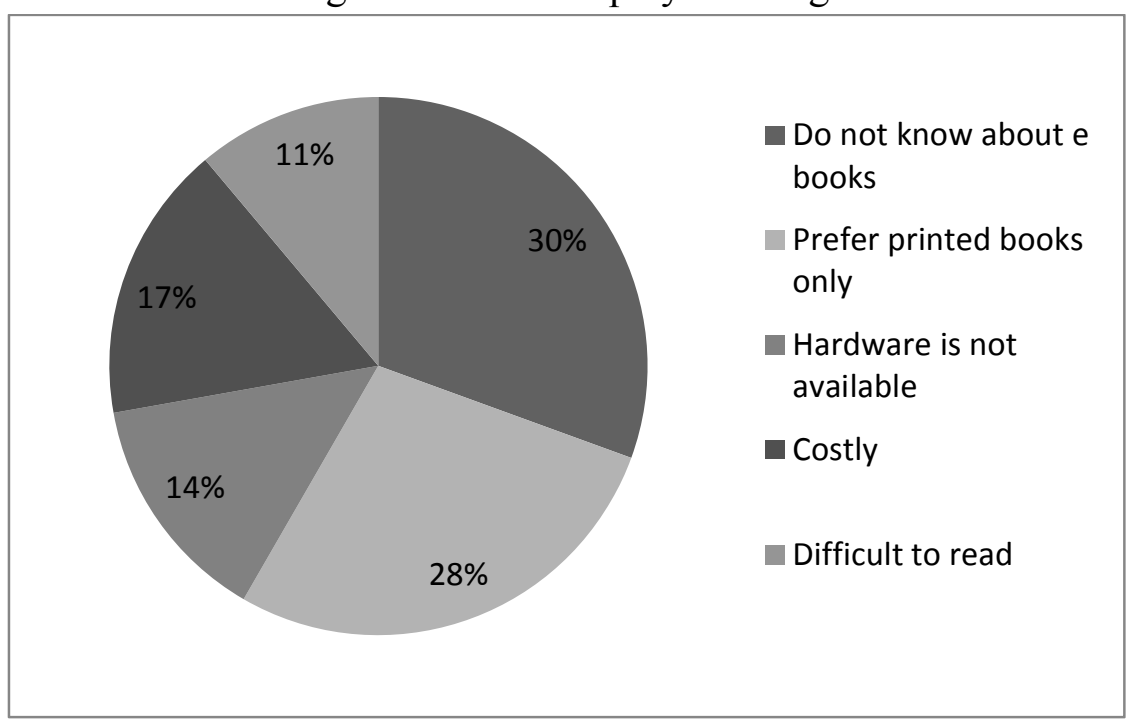

Figure 13: Reasons for not using e-books

According to the reasons for not using e-books about $30 \%$ of respondents do not know about e-books. About $28 \%$ of respondents prefer printed books only. In Tosun (2014) survey $79.1 \%$ of students do not read e-books. In his study the most important factor students prefer printed books is the cost effectiveness. The non-e-book users' future e-book preference at Uva Wellassa University is $94 \%$. This concludes that the non e-.book users are willing to use e-books in the future.

\section{Non e-book users' future e-book preference}

Non e-book users' future e-book preferences are displayed in the Figure 15. About $94 \%$ of non-e-book users are willing to use e-books in the future. 


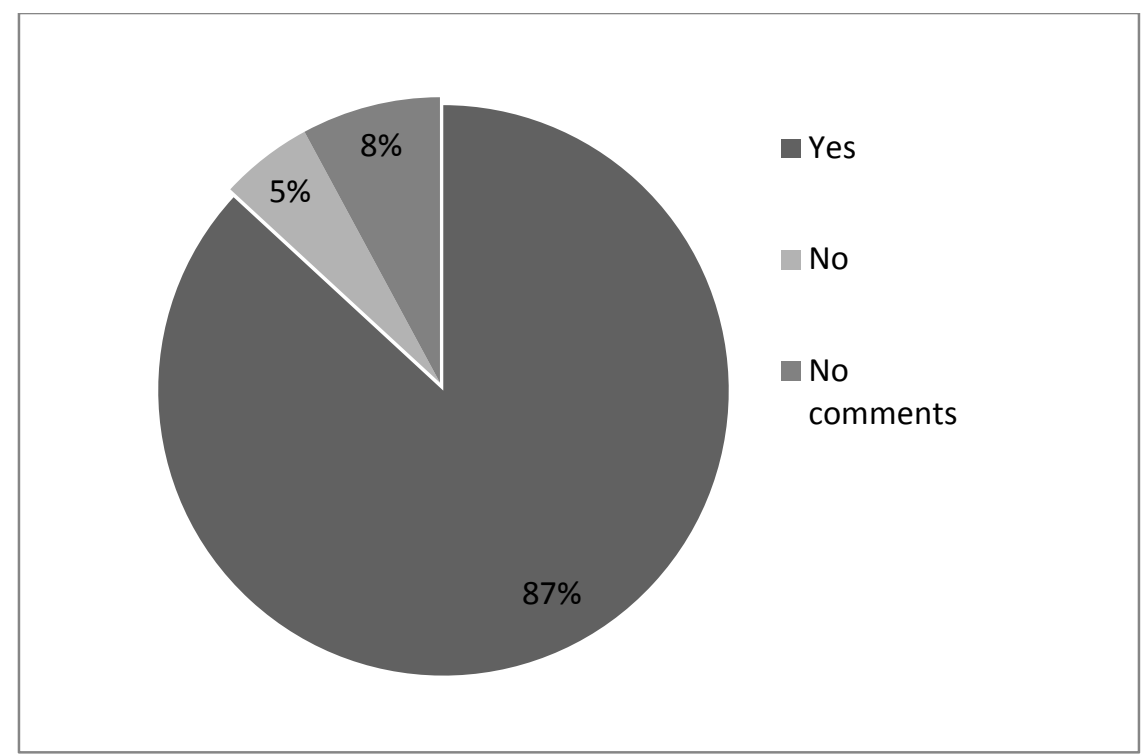

Figure 14: Non e-book users' future e-book preference

\section{The comparative advantages of e-books}

The comparative advantages of e-books are summarized in Table 1. In the open ended question about the comparative advantages of e-books, highest number of undergraduates suggests that e-books are easy to access, easy to use/ handle/read and they are easily portable compared to some heavy printed books and the e-books are user friendly because they are easy to share and easy to obtain free titles. They also suggest that e-books are useful for self/individual learning.

\section{The comparative disadvantages of e-books}

The comparative disadvantages of e-books are summarized in Table 2. In the open ended question about the comparative disadvantages of e-books, highest number of undergraduates suggests that limited number of e-books is available and not enough free titles available. They also mention that e-books are costly. They mention that e-books are not eye friendly as much as printed books, therefore uncomfortable. In Tosun's, 2014 survey the most important factor students prefer printed books is the cost. They mostly had chosen the reasons, "To protect my eye health" and "I like holding the book in my hands" in multiple reasons choosing question. Those reasons coincide with the disadvantages stated by the students in Uva Wellassa University Study. 
Table 1: The comparative advantages of e-books

\begin{tabular}{|c|c|c|c|c|c|}
\hline Advantages of e-books & $\begin{array}{l}1^{\text {st }} \\
\text { year }\end{array}$ & $\begin{array}{l}2^{\text {nd }} \\
\text { year }\end{array}$ & $\begin{array}{l}3^{\text {rd }} \\
\text { year }\end{array}$ & $\begin{array}{l}4^{\text {th }} \\
\text { year }\end{array}$ & Total \\
\hline $\begin{array}{l}\text { Easy to find necessary information, pages } \\
\text { (Quick search, find options available) }\end{array}$ & - & 2 & 3 & 7 & 12 \\
\hline Save time/ Quick in comparison & 1 & - & 2 & 2 & 5 \\
\hline $\begin{array}{l}\text { Easy to access, easy to use/ handle/read, } \\
\text { portable (Some printed books are heavy), } \\
\text { easy to obtain free titles, easy to share, User } \\
\text { friendly }\end{array}$ & 13 & 6 & 23 & 28 & 70 \\
\hline Can use any time & 4 & - & - & 3 & 7 \\
\hline $\begin{array}{l}\text { No desk space needed like printed books/ } \\
\text { Can store within a limited space }\end{array}$ & - & - & 2 & 5 & 7 \\
\hline Useful for self/individual learning & 4 & 5 & 5 & 12 & 26 \\
\hline $\begin{array}{l}\text { Easy to access through a laptop, personal } \\
\text { computer or smart mobile phone }\end{array}$ & 1 & - & 1 & 1 & 3 \\
\hline $\begin{array}{l}\text { Compared to printed books e-books are } \\
\text { long-lasting }\end{array}$ & 1 & 1 & 1 & 1 & 4 \\
\hline $\begin{array}{l}\text { Can access new book versions and fresh } \\
\text { information }\end{array}$ & - & 1 & 7 & 6 & 14 \\
\hline $\begin{array}{l}\text { New generations are technology biased and } \\
\text { e- books are very suitable adaptation to this } \\
\text { new reader society }\end{array}$ & - & 1 & 1 & 2 & 4 \\
\hline $\begin{array}{l}\text { Since free titles are available cheaper than } \\
\text { printed books/ do not have to buy whole } \\
\text { book to read part of it. }\end{array}$ & - & - & 4 & & 4 \\
\hline Easy to make copies & - & - & 1 & 1 & 2 \\
\hline $\begin{array}{l}\text { e-books have extra facilities such as adding } \\
\text { book marks, comments and writing short } \\
\text { notes, highlighting text or copying etc. }\end{array}$ & - & - & 1 & 1 & 2 \\
\hline $\begin{array}{l}\text { Single copy can be accessed by many at the } \\
\text { same time }\end{array}$ & - & - & 1 & 3 & 4 \\
\hline
\end{tabular}

\section{Additional comments of the undergraduates about e-books}

Additional comments of the undergraduates are summarized in Table 3. The open ended question about additional comments section highest number of undergraduates suggests that it will be highly valuable if they can have an ebook collection for the university library which can be access from the library as well as remotely. They also suggest that it is much useful for the user if all the printed books in the library are available in e-book format. 
Table 2: The comparative disadvantages of e-books

\begin{tabular}{|c|c|c|c|c|c|}
\hline Disadvantages of e-books & $\begin{array}{l}1^{\text {st }} \\
\text { year }\end{array}$ & $\begin{array}{l}2^{\text {nd }} \\
\text { year }\end{array}$ & $\begin{array}{l}3^{\text {rd }} \\
\text { year }\end{array}$ & $\begin{array}{l}4^{\text {th }} \\
\text { year }\end{array}$ & $5^{\text {th }}$ \\
\hline $\begin{array}{l}\text { Limited number available/ not enough free } \\
\text { titles available/Costly }\end{array}$ & 2 & 1 & 13 & 14 & 30 \\
\hline $\begin{array}{l}\text { Some free e-book access is limited to certain } \\
\text { regions of the world. Cannot access from Sri } \\
\text { Lanka }\end{array}$ & 1 & - & 2 & - & 3 \\
\hline $\begin{array}{l}\text { Some of the available free e-books are not in } \\
\text { good quality }\end{array}$ & 1 & - & - & 2 & 3 \\
\hline $\begin{array}{l}\text { Not eye friendly as much as printed books/ } \\
\text { Uncomfortable }\end{array}$ & 3 & 3 & 11 & 5 & 22 \\
\hline Difficult to read compared to printed books & - & 1 & 2 & - & 3 \\
\hline Searching free titles is time consuming & 2 & - & - & 2 & 4 \\
\hline $\begin{array}{l}\text { Cannot access them all the time, since } \\
\text { hardware and software should be available }\end{array}$ & 1 & 1 & 8 & 5 & 15 \\
\hline $\begin{array}{l}\text { Sometimes need to have an internet or other } \\
\text { network connection to access e-books. } \\
\text { Internet connection can be costly }\end{array}$ & - & - & 4 & - & 4 \\
\hline Can be destroyed/ deleted easily & 1 & - & - & - & 1 \\
\hline $\begin{array}{l}\text { e-book reading facilities are not available to } \\
\text { everyone due to hardware/software } \\
\text { unavailability }\end{array}$ & 2 & 1 & 5 & 1 & 9 \\
\hline $\begin{array}{l}\text { Use of e-books can be affected by external } \\
\text { factors such as network failures and hardware } \\
\text { problems }\end{array}$ & 1 & 1 & - & - & 2 \\
\hline $\begin{array}{l}\text { To access e books sometimes we have to } \\
\text { download unwanted software. At the same } \\
\text { time we have to take the risk of viruses and } \\
\text { nuisance of advertisements displayed with } \\
\text { free versions. }\end{array}$ & 1 & - & - & - & 1 \\
\hline Lack of knowledge about e-books & - & 1 & 3 & - & 4 \\
\hline $\begin{array}{l}\text { All the books are not available in e-book } \\
\text { format }\end{array}$ & - & - & 1 & 2 & 3 \\
\hline $\begin{array}{l}\text { If libraries do not develop e-book collections } \\
\text { users might abandon the libraries with the } \\
\text { high popularity of e-book access/ Printed } \\
\text { book usage can be reduced due to e-books }\end{array}$ & - & - & 1 & 6 & 7 \\
\hline $\begin{array}{l}\text { Real reading experience cannot be obtain } \\
\text { through e-books }\end{array}$ & - & - & 1 & 2 & 3 \\
\hline $\begin{array}{l}\text { Comparison of information in different pages } \\
\text { in an e-book is difficult than with a printed } \\
\text { book }\end{array}$ & - & - & - & 1 & 1 \\
\hline
\end{tabular}


Table 3: Additional comments of the undergraduates about e-books

\begin{tabular}{|l|c|c|c|c|c|}
\hline Comments & $\begin{array}{l}\mathbf{1}^{\text {st }} \\
\text { year }\end{array}$ & $\begin{array}{l}\mathbf{2}^{\text {nd }} \\
\text { year }\end{array}$ & $\begin{array}{l}\mathbf{3}^{\text {rd }} \\
\text { year }\end{array}$ & $\begin{array}{l}\mathbf{4}^{\text {th }} \\
\text { year }\end{array}$ & Total \\
\hline $\begin{array}{l}\text { It is much useful for the user if all the printed books } \\
\text { in the library are available in e-book format }\end{array}$ & 4 & 5 & 2 & 11 & 22 \\
\hline It is useful if more free titles available & 3 & 1 & 1 & 6 & 11 \\
\hline It is hard to find free titles & 1 & - & - & - & 1 \\
\hline $\begin{array}{l}\text { It will be highly valuable if we can have an e-book } \\
\text { collection for our library/ e-book library collection } \\
\text { which can be access from the library as well as } \\
\text { remotely }\end{array}$ & 1 & 6 & 8 & 10 & 25 \\
\hline $\begin{array}{l}\text { Both e-books and printed books are valuable in } \\
\text { educational purposes. They should be available } \\
\text { side by side in libraries for users. }\end{array}$ & 1 & - & 2 & - & 3 \\
\hline $\begin{array}{l}\text { Most traditional libraries do not have e-book } \\
\text { collections. It is a huge disadvantage to technology } \\
\text { biased new generation. }\end{array}$ & - & 1 & - & - & 1 \\
\hline $\begin{array}{l}\text { E-books can be considered as a good preservation } \\
\text { method to their printed versions/ Printed books } \\
\text { should convert to e-books and should be available } \\
\text { in these dual formats. }\end{array}$ & - & - & 2 & - & 2 \\
\hline $\begin{array}{l}\text { E-books should be available with Multilingual } \\
\text { option }\end{array}$ & - & - & 2 & - & 2 \\
\hline
\end{tabular}

\section{Conclusions and Recommendations}

The survey concludes that there are a high percentage of undergraduates who use e-books. It also reveals that the non-e-book users' future e-book preference is very high. A highest number of non-e-book users are unaware of e-books. According to the results the students use equipment such as personal computers and laptops than the e-readers. They also prefer PDF format than any other format. Students mostly use e-books for education purpose. Mostly they are using e-book free titles. According to both e-book user and non-ebook user, e-books will be used more and more in the purpose of education in the future in Sri Lanka.

The responses of open ended questions conclude that e-books are easy and user friendly. The disadvantages of e-books are limited number is available and there are not enough free titles available. These findings strongly suggest the greater need of having e-book repositories in university libraries, where free access to e-books can be provide to any number of users at any given time. 
The collection development strategies should be diverted to obtain e-books as per the needs of the students.

\section{References}

Chiong, C., Ree, J., Takeuch, L., \& Erickson, I. (2012). Print Books vs. ebooks. Retrieved from http://www.joanganzcooneycenter.org/wpcontent/uploads/2012/07/jgcc_ebooks_quickreport.pdf (Accessed on May 26, 2015,)

Li, C., Poe, F., Potter, M., Quigley, B., \& Wilson, J. (2011). UC Libraries Academic e-Book Usage Survey - academic_ebook_usage_survey. pdf. Retrieved from http://www.cdlib.org/services/uxdesign/ docs/2011/academic_ebook_usage_survey.pdf (Accessed on May May 25, 2015)

Mashroofa, M. (2013). Requirements of Net Generation towards university libraries in Sri Lanka. Journal of the University Librarians Association of Sri Lanka, 16(2). http://doi.org/10.4038/ jula.v16i2.5202

Rainie, L., \& Duggan, M. (2012, December 27). E-book Reading Jumps; Print Book Reading Declines. Retrieved from http://libraries.pewinternet.org/2012/12/27/e-book-reading-jumpsprint-book-reading-declines/

Renner, R. A. (n.d.). eBooks - Costs and Benefits to Academic and Research Libraries. Retrieved from http://static.springer.com/sgw/documents/ 1343302/application/pdf/eBook_Costs+and+benefits+to+ARL (Accessed on June 09, 2015)

Survey of e-bookUsage in U.S. Academic Libraries. (2012). Retrieved from http://www.library.arkansas.gov/PublicLibraryServices/Documents/E book-Usage-Report-Academic.pdf (Accessed on June 22, 2015)

Tosun, N. (2014, January). A study on reading printed books or e-books: reasons for student-teachers preferences. Retrieved from http://files.eric.ed.gov/fulltext/ EJ1018172.pdf (Accessed on June 23, 2015)

Woody, W. D., Daniel, D. B., \& Baker, C. A. (2010). E-books or textbooks: Students prefer textbooks. Retrieved from http://clintlalonde.net/wpontent/uploads/2013/08/Woody-et-al.-2010-E-books-or-textbooksStudents-prefer-textbooks.pdf (Accessed on June 23, 2015) 